TOMASZ WESOŁOWSKI (Białystok)

\title{
„ANTI-KOMMISSAR-FLUGBLÄTTER"- ROLA NIEMIECKICH ULOTEK PROPAGANDOWYCH W PODWAŻANIU AUTORYTETU KADRY POLITYCZNEJ ARMII CZERWONEJ W LATACH 1941-1942
}

II wojna światowa wykazała wyjątkowe znaczenie, toczonej równolegle z klasycznymi działaniami zbrojnymi, wojny psychologicznej. Różnorodność jej form, a także wyjątkowa intensyfikacja, nie znalazły sobie równych ani w okresie ja poprzedzającym, ani też w latach późniejszych. Jedną z najprostszych, a zarazem najskuteczniejszych form wojny psychologicznej okazały się kampanie toczone za pomocą masowych ulotek propagandowych. Nie ulega wątpliwości, iż palmę mistrzostwa w tej dziedzinie wojny psychologicznej należy przyznać propagandzie III Rzeszy. W rękach niemieckich propagandzistów ulotki okazały się wyjątkowo groźną bronią, zaś prowadzone przez nich w latach 1941-1942 propagandowe akcje skierowane przeciw kadrze politycznej Armii Czerwonej stanowią przykład zbrodniczych prób wykorzystania ich efektów.

Przygotowując się w 1941 r. do uderzenia na ZSRS, niemieckie władze wojskowe wiele uwagi poświęcały funkcjonowaniu w szeregach armii przyszłego przeciwnika kadry politycznej - elementu niespotykanego w siłach zbrojnych państw pokonanych wcześniej przez Wehrmacht. Wydaje się jednak, iż Niemcy do pewnego stopnia przeceniali wówczas rzeczywisty wpływ kadry politycznej na żołnierzy sowieckich. Niewątpliwie zaciążył na tym wytworzony i rozpowszechniony w latach 1937-1940 obraz sowieckiego oficera politycznego, przedstawiający go jako wszechwładnego komisarza, dysponującego możliwością sprawowania pełnej i nieograniczonej kontroli nad podległymi żołnierzami, a także dowodzącymi nimi oficerami. Oczywiście nie należy negować pojawienia się tego rodzaju zjawisk w Armii Czerwonej po sierpniu 1937 r., kiedy w trakcie rozpoczynającej się czystki przywró- 
cono zlikwidowaną jeszcze w 1922 r. funkcję komisarzy wojskowych, zajmujących równoległe stanowiska $z$ dowódcami liniowymi ${ }^{1}$. Tragiczne skutki przeprowadzonej w latach 1937-1938 czystki w Armii Czerwonej, ewidentny i szkodliwy, co ujawniła obfitująca w porażki kampania fińska, przerost kompetencji komisarzy wojskowych, doprowadziły jednak do przywrócenia w sierpniu 1940 r. zasad jednoosobowego dowodzenia i likwidacji stanowisk komisarzy wojskowych. Oficerów politycznych, pełniących funkcje komisarzy jednostek, przeniesiono wówczas na utworzone stanowiska zastępców dowódców ds. politycznych, znacznie ograniczając kompetencje, szczególnie $\mathrm{w}$ stosunku do dowodzących jednostkami oficerów liniowych ${ }^{2}$.

Pomimo to Naczelne Dowództwo Wehrmachtu w 1941 r. nadal upatrywało w sowieckiej kadrze politycznej największego bodajże zagrożenia, spodziewając się po komisarzach i politrukach fanatycznego stawiania oporu, zmuszania do podobnych zachowań oficerów liniowych i żołnierzy, a także potencjalnego, szkodliwego wpływu na jeńców wojennych. Stąd też prowadzone od marca 1941 r. przygotowania doprowadziły do wydania 6 czerwca $1941 \mathrm{r}$. brzemiennych w skutki Zasad traktowania komisarzy politycznych, znanych szerzej pod nazwą rozkazu o komisarzach - Kommissarbe$f e h l^{3}$. W rozkazie tym sowieckich oficerów politycznych określano mianem „właściwych nosicieli oporu, pełnego nienawiści, okrucieństwa i nieludzkości w traktowaniu jeńców" i „twórców barbarzyńskich, azjatyckich metod walki" 4. W myśl Kommissarbefehl schwytanych sowieckich oficerów politycznych należało rozstrzeliwać natychmiast po wzięciu do niewoli. Naczelne Dowództwo Wehrmachtu nie spodziewało się jednak masowego poddawania się sowieckich oficerów politycznych do niewoli, podkreślając konieczność przeprowadzenia intensywnych akcji propagandowych, mających na celu osłabienie siły stawianego przez nich oporu.

1 Prikaz c objavlenijem postanovlenija CIK $i$ SNK SSSR „Ob utverždenii položenija o voennych komissarach Raboče-Krestjanskoj Krasnoj Armii”, 20 avgusta $1937 \mathrm{~g}$., w: Prikazy Narodnogo komissara oborony SSSR 1937 - 21 ijunja 1941 g., Russkij Archiv, Moskva 1994, t. XIII, s. 24-25.

2 Prikaz s objavlenijem Ukaza Prezidiuma Verchnogo Soveta SSSR „Ob ukreplenii edinonačalija v Krasnoj Armii $i$ Voenno-Morskom Flote, 14 avgusta 1940 g., w: Prikazy Narodnogo komissara oborony SSSR..., s. 163.

3 H. A. Jacobsen, Kommissarbefehl und Massenexekutionen sowjetischer Kriegsgefangener, w: Anatomie des SS-Staates, t. II: Konzentrationslager, Kommissarbefehl, Judenverfolgung, Olten-Freiburg im Breisgau 1965, s. 189-191.

4 lbidem. 
W kwietniu 1941 r. w Ministerstwie Propagandy Rzeszy utworzono osobny wydział specjalny (niem. Spezialabteilung des Propagandaministeriums), który we współpracy z Wydziałem Propagandy Naczelnego Dowództwa Wehrmachtu (niem. Abteilung für Wehrmachtpropagánda im Oberkomando der Wehrmacht, $O K W / W P r$ ) przystąpił do opracowania zasad działań propagandowych wymierzonych w Armię Czerwoną, a w szczególności jej kadrę polityczną ${ }^{5}$. Za potencjalnie najskuteczniejszą, w warunkach planowanych działań Blitzkriegu, uznano masowe kampanie propagandowe za pomocą ulotek. W tym celu, w warunkach zachowania najściślejszej tajemnicy, przystąpiono do opracowania i tłumaczenia na języki wschodnie (rosyjski, ukraiński i białoruski) serii wzorów ulotek, przeznaczonych do rozpowszechniania na froncie wschodnim. Przewidywano przy tym, iż główny ciężar rozpowszechniania ulotek spadnie na jednostki Luftwaffe, nadzorowane przez funkcjonariuszy aparatu propagandowego $z$ przydzielanych do poszczególnych związków operacyjnych jednostek propagandowych.

Do celów propagandy na przygotowywanym froncie wschodnim przygotowano łącznie 14 samodzielnych oddziałów w sile kompanii. Grupa Armii „Północ" otrzymała 3 oddziały: do 18 Armii przydzielona została 621 kompania propagandowa (niem. Propagandakompanie, PK), do $16 \mathrm{Ar}$ mii 501 kompania propagandowa, zaś do 4 Grupy Pancernej 694 kompania propagandowa wojsk pancernych (niem. Panzerpropagandakompanie, Pz.PK). Z kolei Grupa Armii „Środek" otrzymała 4 jednostki propagandowe: do 9 Armii przydzielono 612 kompanię propagandową, do $4 \mathrm{Ar}$ mii 698 kompanię propagandową. Wchodzące w skład armii 2 i 3 Grupy Pancerne otrzymały kolejno 693 oraz 697 kompanie propagandowe wojsk pancernych. Natomiast Grupa Armii „Południe” otrzymała 4 oddziały propagandowe: do 6 Armii została przydzielona 637 kompania propagandowa, do 17 Armii 666 kompania propagandowa, do 11 Armii 695 kompania propagandowa, zaś do 1 Grupy Pancernej 691 kompania propagandowa wojsk pancernych. Jednostki propagandowe znalazły się również w przygotowywanych do uderzenia na ZSRS związkach Luftwaffe: do 1 Floty Powietrznej przydzielono 1 kompanię korespondentów wojennych wojsk powietrznych (niem. Luftwaffekriegsberichterkompanie, Lw. KBK), do 2 Floty Powietrznej 2 kompanię korespondentów wojennych wojsk powietrznych, natomiast do 4 Floty Powietrznej 4 kompanię korespondentów wojennych wojsk po-

5 O. Buchbender, H. Schuh, Heil Beil! Flugblattpropaganda im Zweiten Weltkrieg. Dokumentation und Analyse, Stuttgart 1974, s. 49-50. 
wietrznych ${ }^{6}$. W skład każdej z kompanii propagandowych wchodziły: sekcja dowodzenia (niem. Kompanietrupp), 2 lekkie plutony korespondentów wojennych (niem. leichter Kriegsberichterzug), 1 ciężki pluton korespondentów wojennych (niem. schwerer Kriegsberichterzug), pluton propagandowy (niem. Propagandazug), kolumna robocza (niem. Arbeistaffel) oraz tabor (niem. Gefechtstroß). W skład plutonu propagandowego wchodziła sekcja ulotkowa (niem. Flugblatttrupp). Każda z kompanii propagandowych, zgodnie z etatem, liczyła łącznie 22 oficerów, 3 urzędników wojskowych, 41 podoficerów i 85 szeregowców? ${ }^{7}$.

Początkowo zakładano, iż kompanie propagandowe będą odpowiadać jedynie za rozpowszechnianie ulotek propagandowych, przygotowywanych przez Wydział Propagandy Wehrmachtu. Wzory ulotek miały być opracowywane i drukowane w berlińskiej centrali. Do zadań frontowych oddziałów propagandowych miał należeć nadzór nad doraźnym doborem odpowiednich wzorów ulotek oraz ich rozrzucaniem, a także gromadzenie danych na temat skuteczności oddziaływania tego rodzaju akcji propagandowych. Niezależnie od tego, poszczególne oddziały propagandowe wyposażono w odpowiedni sprzęt, umożliwiający im opracowywanie własnych wzorów ulotek w strefie frontowej. Proste urządzenia poligraficzne, posiadane przez kompanie propagandowe, nie zapewniały jednak mózliwości druku ulotek w odpowiednio dużych nakładach. W związku z tym planowano przesyłanie wzorów ulotek, opracowanych przez sekcje ulotkowe poszczególnych kompanii propagandowych, do berlińskiej centrali. Tam, po zaakceptowaniu i ewentualnych poprawkach, miały być kierowane do drukarni i przewożone z powrotem na front. W późniejszym okresie walk na froncie wschodnim druk ulotek usprawniono poprzez wykorzystanie przydzielanych dowództwom armii specjalnych, odpowiednio wydajnych drukarni polowych instalowanych w pociągach.

Do 6 czerwca 1941 r. w berlińskim Wydziale Propagandy przygotowano łącznie $22 \mathrm{mln}$ antysowieckich ulotek w 9 wzorach. Drukiem ulotek zajmowały się wyselekcjonowane berlińskie zakłady poligraficzne, strzeżone przez specjalne placówki Gestapo. W przeciągu kilku dni poprzedzających uderzenie ma ZSRS ulotki przetransportowano do dowództw poszczególnych grup armii, gdzie następował ich rozdział do poszczególnych związków taktycz-

6 H. Wedel, Die Propagandatruppen der deutscher Wehrmacht, Neckargemünd 1962, s. 54 .

7 O. Buchbender, H. Schuh, op. cit., s. 14. 
nych, w szczególności zaś do jednostek lotniczych, przewidzianych do ich rozrzucania.

Gros przygotowanych ulotek skierowanych było do szeregowych żołnierzy Armii Czerwonej. Ich treść oparta była na zastosowaniu kombinacji trzech argumentów: nakreślenia w czarnych barwach tragicznej sytuacji żołnierzy wraz ze wskazaniem winnych tego stanu (Stalin, władze sowieckie, Żydzi itp.), przedstawienia atrakcyjnej alternatywy (możliwość przeżycia, dobre traktowanie w niewoli, lepsze wyżywienie, szybki powrót do rodzin itp.) oraz apelu wzywającego do dezercji z Armii Czerwonej lub rezygnacji $z$ walki i biernego poddania się do niewoli. Tworząc hasła ulotek, niemieccy propagandziści odwoływali się również do społecznych resentymentów (m.in. obietnice reformy rolnej) i stereotypów. Przygotowywane ulotki antykomisarskie nie stanowiły wówczas odrębnej grupy. Treści skierowane przeciw kadrze politycznej umieszczano w niemal wszystkich ulotkach, których adresatami byli nie tylko szeregowi żołnierze Armii Czerwonej, ale również oficerowie. Niemieccy propagandziści liczyli tu na ożywienie dawnych animozji i wskazanie kadrze oficerskiej najprostszych możliwości rewanżu za niedawną wszechwładzę i represje.

Treści skierowane przeciw kadrze politycznej Armii Czerwonej zawierała już pierwsza ulotka przygotowana na front wschodni, oznaczona kodem 000111 RA: „Staliście się pańszczyźnianymi niewolnikami Stalina i jego żydowskich komisarzy, którym oczywiście nie żal, że nadwyrężacie się w kołchozach, uginacie się pod ciężarem stachanowszczyzny lub giniecie w obozach koncentracyjnych". W podobnym tonie utrzymane były pozostałe ulotki pierwszej serii. Pojawiają się w nich „żydowscy komisarze i ich lokaje" (ulotka 000112 RA), określani jako „mordercy”, „dręczyciele”, ;szpicle" (ulotka $000117 \mathrm{RA}$ ). Propagandziści niemieccy nawet nie próbowali ukrywać, jaki los spotka schwytanych oficerów politycznych. Ulotka sygnowana kodem $000118 \mathrm{RA}$ obwieszczała, iż sowiecką kadrę polityczną czeka sąd, zaś „wielu komisarzy i politruków zostanie powieszonych" 8 .

Opracowane jeszcze przed atakiem ulotki pierwszej serii intensywnie rozrzucano od 22 czerwca do końca lipca 1941 r. Trudno ocenić ich rzeczywistą skuteczność w odniesieniu do całości korpusu oficerskiego i żołnierzy Armii Czerwonej. Pojedyncze znane przypadki świadczą o uzyskaniu przez niemieckich propagandzistów raczej ograniczonych efektów. Na ich podstawie można stwierdzić, iż niemieckiej propagandzie nie udało się zainicjować

8 O. Buchbender, Das tönende Erz. Deutsche Propaganda gegen die Rote Armee im Zweiten Weltkrieg, Stuttgart 1978, s. 98. 
masowych przypadków niesubordynacji żołnierzy sowieckich wobec oficerów politycznych. Wrogą postawę wobec komisarzy żołnierze ujawniali najczęściej dopiero w trakcie kapitulacji, wskazując Niemcom usiłu jących ukryć się w tłumie jeńców pracowników politycznych. Stosunkowo najbardziej nagłośnionym przykładem takiej postawy czerwonoarmistów jest sprawa uczestnika obrony brzeskiej cytadeli - komisarza pułkowego Jefima Mojsiejewicza Fomina, pełniącego wówczas obowiązki zastępcy ds. politycznych dowódcy 6 Dywizji Strzeleckiej. 30 czerwca 1941 r., podczas kapitulacji grupy żołnierzy 84 pułku strzeleckiego ranny Fomin usiłował ukryć się wśród żołnierzy w mundurze szeregowca. Został zadenuncjowany przez jednego z sowieckich żołnierzy i natychmiast rozstrzelany ${ }^{9}$.

Ulotkowa akcja antykomisarska spotkała się z aktywną kontrpropagandą, prowadzoną przez kadrę polityczną Armii Czerwonej. Informacje o automatycznych egzekucjach wszystkich wziętych do niewoli funkcjonariuszy politycznych rozeszły się po całym froncie w przeciągu kilku pierwszych tygodni. Gwałtowne przeciwdziałanie kadry politycznej Armii Czerwonej, w połączeniu z szybko rozprzestrzeniającymi się wzdłuż frontu informacjami o brutalnym traktowaniu wszystkich sowieckich jeńców przez oddziały Wehrmachtu i SS przyczyniły się do spadku ilości poddających się żołnierzy sowieckich.

Sowieckie Naczelne Dowództwo natychmiast zdało sobie sprawę z wyjątkowo trudnej sytuacji kadry politycznej, pozbawionej odpowiednich prerogatyw w obliczu najwyższego zagrożenia. 16 lipca 1941 r. Prezydium Rady Najwyższej ZSRS wydało dekret $O$ reorganizacji organów propagandy politycznej $i$ wprowadzeniu instytucji komisarzy wojskowych $w$ Robotniczo-Chtopskiej Armii Czerwonej. Dzień później rozkaz Stawki Naczelnego Dowództwa nr 00401 usankcjonował wprowadzenie postanowień dekretu w życie $^{10}$. Zgodnie $z$ tym rozkazem Główny Zarząd Propagandy Politycznej Armii Czerwonej natychmiast przekształcono w Główny Zarząd Polityczny Armii Czerwonej, zaś zarządy propagandy politycznej frontów i okręgów wojskowych oraz wydziały propagandy politycznej armii i dywizji przeformowano w odpowiednie zarządy i wydziały polityczne. Dotychczasowi zastępcy ds. politycznych dowódców związków operacy jnych i taktycznych Armii Czerwonej zostali przesunięci na odtworzone stanowiska komisarzy woj-

9 S. Smirnov, Brestskaja krepost, Minsk 1991, s. 171-172.

10 Prikaz Stavki VK Nr 00401 o reorganizacii organov političeskoj propagandy $i$ vvedenii instituta voennych komissarov, w: Stavka VGK. Dokumenty i materialy. 1941 god. Russkij Archiv, Moskva 1996, t. XVI, cz. 1, s. 77. 
skowych tych związków. Zastępców szefów likwidowanych wydziałów propagandy politycznej przesunięto na stanowiska szefów nowo powołanych wydziałów politycznych, tworząc dodatkowe stanowiska ich zastępców ${ }^{11}$.

Tego rodzaju reorganizacja pionu politycznego w oczywisty sposób powiększała ilość personelu politycznego, przywracając jednocześnie jego wcześniejsze szerokie kompetencje i pozycję. Praktycznym wymiarem podjętych kroków był powrót do dawnego systemu dowodzenia - wszechwładzy komisarzy i ich całkowitej kontroli nad kadrą oficerską. Ubocznym efektem przywrócenia pozycji komisarzy wojskowych jednostek było zaprzestanie przez wielu z nich tradycyjnej pracy szkoleniowej i wychowawczej, przy permanentnym nadużywaniu władzy i kompetencji, prowadzącym do zaostrzenia represji w stosunku do podoficerów i szeregowych. Ponowne pojawienie się starych patologii w armii szybko odnotowało Naczelne Dowództwo Armii Czerwonej, zaś ich stopniowe zaostrzanie się doprowadziło w końcu do reakcji w postaci piętnu jącego je rozkazu ludowego komisarza obrony $\mathrm{Nr} 0391^{12}$. Niezależnie od tego zauważony został wzrost dyscypliny w oddziałach Armii Czerwonej oraz spadek ilości żołnierzy poddających się do niewoli, wynikający głównie $z$ rozpowszechnianych przede wszystkim przez kadrę polityczną informacji o brutalnym traktowaniu jeńców w niemieckiej niewoli.

Sytuacja ta zmusiła Wydział Propagandy Wehrmachtu do uwzględnienia zmian w kampanii ulotkowej już na przełomie lipca i sierpnia $1941 \mathrm{r}$. Opracowano wówczas i skierowano do druku szereg ulotek, których głównym celem miało być zaprzeczenie informacjom o niemieckich okrucieństwach wobec jeńców wojennych i tym samym podważenie autorytetu najgorliwiej rozpowszechniających je oficerów politycznych. Na początku sierpnia $1941 \mathrm{r}$. rozpoczęto masowe rozrzucanie ulotki sygnowanej kodem $121 \mathrm{RA}$. Awers ulotki przedstawiał fotografię rannego sowieckiego żołnierza, opatrywanego i pojonego przez oficerów niemieckiej służby medycznej. Na rewersie znalazła się następująca treść: „Towarzyszu Czerwonoarmisto! Spokojnie przechodź do Niemców. Jeśli jesteś głodny, nakarmią cię. Jeśli jesteś ranny, niemieccy lekarze udzielą ci pierwszej pomocy. Durnie-politrucy radzą ci założyć ubranie cywilne, jeżeli pozostaniesz w tyle za swoim pododdziałem. Uprzedzamy cię! Żołnierz w cywilnym ubraniu uważany jest nie za żołnierza, lecz rozbójnika. Z rozbójnikiem nie cackają się! Politrucy kłamią, jakoby Niemcy wysyłają jeńców do katorżniczej pracy w Niemczech. To bezczelne kłamstwo!

11 Ibidem.

12 Prikaz Narodnogo komissara oborony $\mathrm{Nr} 0391$ „O faktach podmeny vospitatelnoj raboty repressijami”, 4 oktjabrja 1941 g., „Voenno-Istoričeskij Żurnal” 1989, nr 9, s. 29-30. 
Goń łgarzy! Niemcy dobrze odnoszą się do jeńców. Politrucy rozkazują ci niszczyć wszystko podczas odwrotu. Zniszczeniem zapasów i plonów nie zatrzymasz zwycięskiego posuwania się wojsk niemieckich, a narazisz siebie i swoją rodzinę na głód i nędzę. Strzeż mienia społecznego - przechodź do Niemców!" ${ }^{13}$. Ulotka 121 RA rozpowszechniana była przez kilka kolejnych miesięcy, w znacznym stopniu przyczyniając się do wzrostu dezercji wśród żołnierzy Armii Czerwonej i zmuszając jej kadrę polityczną do intensyfikacji doraźnych akcji kontrpropagandowych. Główny Zarząd Polityczny Armii Czerwonej przeprowadził nawet własną akcję ulotkową, rozpowszechniając w tej formie artykuł z czasopisma „Krasnaja Zwiezda”, przypominający o prowadzonych przez Niemców egzekucjach czerwonoarmistów ${ }^{14}$.

Kolejne ulotki niemieckie, których rozpowszechnianie rozpoczęto w sierpniu 1941 r., miały już zdecydowanie bardziej agresywny ton. Pojawiły się na nich wezwania: „Precz z komisarzami! Przechodźcie do Niemców!” (ulotka $123 \mathrm{RA}$ ), „Usuwajcie komisarzy! Usuwajcie Żydów!” (ulotka 124 RA), „Precz z Żydami i komisarzami!” (ulotka 125 RA), „Precz z komisarzami!" (ulotka $136 \mathrm{RA})^{15}$. Charakterystyczne dla tego etapu ulotek i zawartych w nich treści skierowanych przeciw sowieckiej kadrze politycznej było niezmienne łączenie określeń: komisarz i Żyd. Wiązało się to ściśle $\mathrm{z}$ rozpowszechnianym $\mathrm{z}$ kolei przez propagandę niemiecką wizerunkiem sowieckich oficerów politycznych i niezłomnym przekonaniem o żydowskim pochodzeniu większości z nich.

Punktem kulminacyjnym równoległej kampanii antykomisarsko-antysemickiej było opracowanie i rozpowszechnienie, bodajże najbardziej agresywnej i brutalnej w treści ulotki ilustrowanej (niem. Bildflugblatt), sygnowanej kodem $150 \mathrm{RA}$. Ulotka ta powstała na potrzeby zorganizowanej przez Wydział Propagandy Wehrmachtu „wielkiej akcji” (niem. Großaktion) antykomisarskiej na początku września 1941 r. Ulotkę 150 RA przygotowano i wydrukowano w berlińskiej centrali specjalnie na potrzeby tej akcji, osiągając niespotykany dotąd w propagandzie nakład $160 \mathrm{mln}$ egzemplarzy (do tego momentu na całym froncie wschodnim rozpowszechniono łącznie $141 \mathrm{mln}$ ulotek wszystkich wzorów). Nakład ulotki 150 RA przewieziono w dniach

13 O. Buchbender, op. cit., s. 66-67.

14 Direktiva GlavPU RKKA voennym sovetam, načalnikam politupravlenij frontov, armij ob opublikovanii v pečati peredovoj stati "Krasnoj Zvezdy” "Rasstrely nemcami plennych krasnoarmejcev", 10 dekabrja $1941 \mathrm{~g} ., \mathrm{w}$ : Glavnye političeskie organy Voorużennych Sil SSSR v Velikoj Otečestvennoj vojne 1941-1945 gg., Russkij Archiv, Moskva 1996, t. XVII, s. 91.

15 O. Buchbender, op. cit., s. 98. 
3-5 października 1941 r. z berlińskiego lotniska Rangsdorf na front wschodni aż 15 samolotami transportowymi. Awers ulotki 150 RA zawierał hasło: „Bij Żyda-politruka, morda prosi się o cegłę! Komisarze i politrucy zmuszają was do bezsensownego oporu. Pędźcie komisarzy i przechodźcie do Niemców. Przechodźcie do Niemców, posługując się albo hasłem: bij Żyda-politruka, morda prosi się o cegłę! albo przepustką". Hasło zilustrowane było dwoma rysunkami. Na pierwszym przedstawiona została grupa żołnierzy sowieckich, ginących pod ogniem widocznych na horyzoncie pozycji niemieckich. $\mathrm{Z}$ tyłu, za murem, czai się postać oficera politycznego o wyraźnie semickich rysach twarzy. Na drugim rysunku żołnierze idą z podniesionymi rękami w stronę pozycji niemieckich, zaś dwóch z nich bije leżącego politruka. Tekst rewersu ulotki miał uświadamiać odciętym w kotłach oficerom i żołnierzom Armii Czerwonej ich beznadziejne położenie i zachęcać ich do przejścia na stronę wojsk niemieckich, gwarantując dobre traktowanie i kusząc hasłami reformy rolnej. Na rewersie znajdowała się ponadto obowiązkowa wówczas „przepustka”, wraz z tekstem: „Okaziciel niniejszego, nie chcąc bezsensownego przelewu krwi za interesy Żydów i komisarzy, porzuca pokonaną Armię Czerwoną i przechodzi na stronę niemieckich sił zbrojnych" ${ }^{16}$.

Treści antykomisarskie zawarto również w przygotowanych pod koniec lipca 1941 r. ulotkach specjalnych (niem. Spezialflugblätter) sygnowanych kodem 134 St oraz 135 St. Obie ulotki, wydrukowane i rozpowszechnione w łącznym nakładzie $14 \mathrm{mln}$ egzemplarzy, przedstawiały fotografie starszego syna Stalina - st. lejtn. Jakowa Iosifowicza Dżugaszwilego, dowódcy baterii 14 pułku artylerii haubicznej 14 Dywizji Pancernej, wziętego do niewoli w dniu 16 lipca $1941 \mathrm{r}$. w rejonie Witebska. W ulotce 134 St znalazł się fragment: „Na rozkaz Stalina uczą was Timoszenko i wasi komisarze polityczni, że bolszewik nie poddaje się do niewoli. Jednak czerwonoarmiści przez cały czas przechodzą do Niemców. Aby was zastraszyć, komisarze łżą wam, że Niemcy źle obchodzą się z jeńcami. Własny syn Stalina swym przykładem udowodnił, że to kłamstwo! On poddał się do niewoli" ${ }^{17}$.

Sowiecką odpowiedzią na będący m.in. efektem niemieckiej propagandy, chaos dyscyplinarny Armii Czerwonej i ponowny wzrost ilości żołnierzy poddających się do niewoli był rozkaz Stawki Naczelnego Dowództwa nr 270 z 16 sierpnia $1941 \mathrm{r}$. Rozkaz ten stanowił bezprecedensowe połączenie zbioru przykładów waleczności poszczególnych dowódców Armii Czerwonej z serią

16 Ibidem, s. 100-101.

17 Ibidem, s. 68-69. 
Ryc. 1. Ulotka 150 RA (przedruk za O. Buchbenderem, op. cit.)

\section{Бей жида - политрука рожа просит кирпича!}

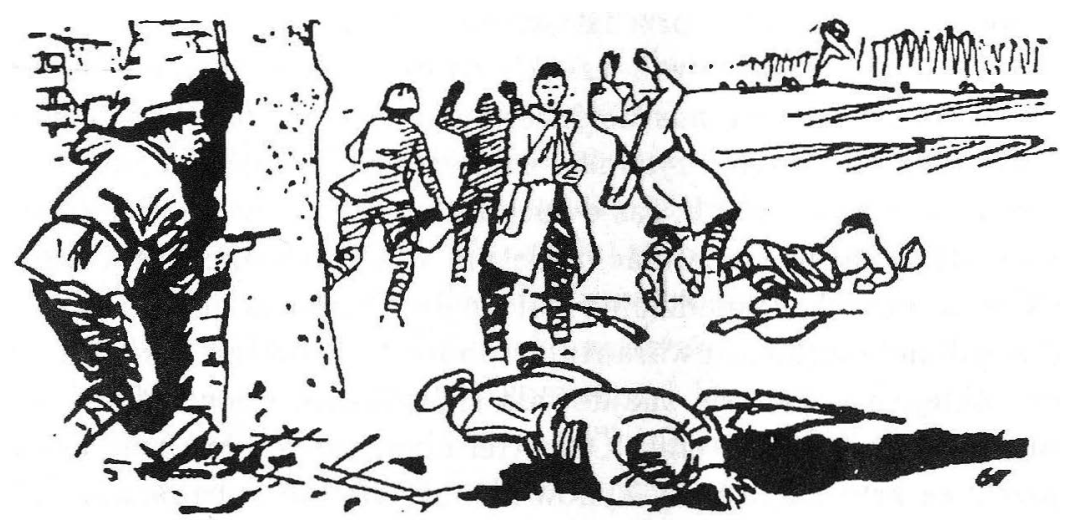

Комисары и политруки прннуждаютв вас к бессмысленіюму сопротивлению.

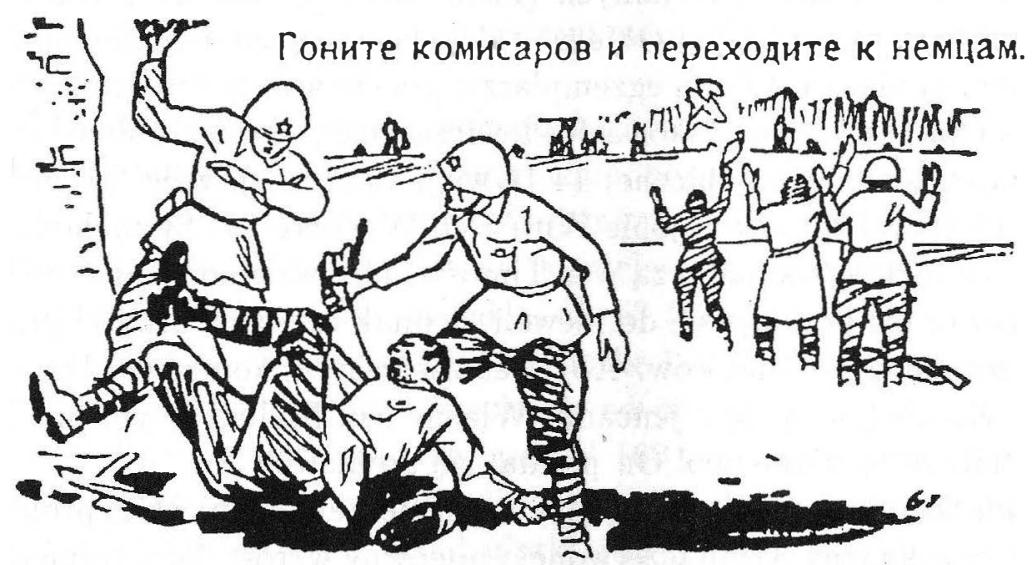

Переходнте $к$ немпам пользуясь либо лозунгом:

\section{Бей жида-политрука, рожа просит кирпича!}


gróźb pod adresem „tchórzy i dezerterów”, których zgodnie z zaleceniem Stalina, należało „unicestwiać" ${ }^{18}$. Zawarte w rozkazie Nr 270 groźby nie ominęły również sowieckiej kadry politycznej: „Jak wiadomo, niektórzy oficerowie i pracownicy polityczni swoim zachowaniem na froncie nie tylko nie stanowią dla czerwonoarmistów wzoru odwagi, uporu i miłości do Ojczyzny, lecz na odwrót, a przy pierwszych poważnych trudnościach w boju, zdzierają z siebie dystynkcje, dezerterują z pola walki" ${ }^{19}$. Rozkaz kończył się poleceniem natychmiastowego zdejmowania ze stanowisk i rozstrzeliwania wszystkich oficerów i pracowników politycznych uchylających się od walki i myślących o kontynuacji odwrotu.

Kolejną, zaplanowaną na październik 1941 r. akcję antykomisarską przeprowadzono przy użyciu ulotki sygnowanej kodem $176 \mathrm{RA}$. Na awersie i rewersie ulotki wykorzystano motyw ilustracji pistoletu, na którego rękojeści (awers) znalazł się tekst: „Przed wami śmierć - za wami śmierć! Oddziały NKWD i politrucy grożąc Naganami pędzą was do boju, pędzą was pod ogień naszych karabinów maszynowych, pod ołowiany grad bomb lotniczych, pędzą na pewną śmierć! Zmuszają was do haniebnego umierania za obce wam interesy! Żołnierze i oficerowie! Przecież jesteście wolnymi ludźmi! Przecież widzicie, że ten bezsensowny przelew krwi nie jest potrzebny ani wam, ani nam. Dość rzeźni! Przechodźcie na naszą stronę! Walczymy o wyzwolenie was ze stalinowskiej przemocy i terroru, o szacunek i wolną pracę!" 20.

W tym okresie pojawiły się również ulotki antykomisarskie, doraźnie wykonywane w poszczególnych niemieckich kompaniach propagandowych. Przykładem tego jest ulotka przygotowana przez 621 kompanię propagandową $w$ pierwszym etapie oblężenia Leningradu. Awers ulotki przedstawiał wizerunek śmierci, ubranej w mundur oficera politycznego ( $\mathrm{z}$ obowiązkowymi gwiazdami na przedramionach), popędzającej pejczem i rewolwerem grupę sowieckich żołnierzy. Rysunkowi towarzyszyło hasło: „Precz z nahajem i Naganem. Walczcie o wolność". Tekst na rewersie wzywał: „Czerwonoarmiści i oficerowie! Gnuśni przestępcy, wasi politrucy i komisarze pędzą was knutem na kolejny bezsensowny bój - z Naganem w ręku gonią was na pewną śmierć. Oni zawsze was oszukiwali. Opowiadali wam o zwycięstwie a co widzicie? Pod niszczącym działaniem niemieckiej artylerii, moździerzy

18 Prikaz Stavki Verchnogo Glavnogo Komandovanija Krasnoj Armii Nr 270, 16 avgusta 1941 g., „Voenno-Istoričeskij Żurnal” 1989, nr 9, s. 26-28.

19 Ibidem, s. 27.

20 O. Buchbender, op. cit., s. 103. 
i czołgów, przechodziliście od jednej klęski do drugiej. Walczyliście bohatersko - lecz wasi przywódcy i komisarze zdradzili was, inaczej armia niemiecka nie stałaby pod Leningradem i nie trzymała miasta w żelaznej obręczy. Politrucy i komisarze rozkazują wam bronić Leningradu. Wasze żony i dzieci, wasze rodziny będą niewinnymi ofiarami bezmyślnej wojny. Oni także, tak jak i wy, legną pod gruzami Leningradu. Jest tylko jeden ratunek od tej bezmyślnej walki. Zabijajcie waszych politruków i komisarzy - oni są waszą śmiercią. Przechodźcie do nas! Przyjmiemy was dobrze i nakarmimy, jak zasługuja na to waleczni żołnierze. Uratujecie tym przed zniszczeniem wasze życie i miasto Leningrad, wraz z całą jego ludnością i historyczną przeszłością. Zapewnicie sobie po wojnie prawo do własnej ziemi i dobry zarobek w nowoczesnej fabryce" 21.

Ogromne straty ponoszone przez Armię Czerwoną objęły również jej korpus oficerski, w tym także kadrę polityczną. W przeciągu kilku miesięcy krwawych walk odwrotowych poległo, zaginęło bez wieści lub zostało rannych kilkanaście tysięcy oficerów pionu politycznego. W ogromnej większości byli to doświadczeni pracownicy polityczni, w wielu wypadkach ze znacznym stażem członkostwa w WKP(b) i służby w Armii Czerwonej. Coraz dotkliwiej odczuwany wiosną 1942 r. brak kadry politycznej dla nowych oraz wciąż odtwarzanych oddziałów Armii próbowano złagodzić doraźnym naborem i przyspieszonym szkoleniem młodszej kadry politycznej. W ten sposób do pionu politycznego wojsk sowieckich zaczęli masowo napływać rezerwiści, pobieżnie szkoleni na kilkumiesięcznych kursach. Rekrutowani byli zazwyczaj spośród nauczycieli i pracowników administracji państwowej niższego szczebla. Wielu z nich posiadało bardzo krótki staż przynależności do struktur partyjnych i komsomolskich. Ich mierne wyszkolenie wojskowe, a także częsty brak doświadczenia w pracy wychowawczej i propagandowej szybko odbijały się na dyscyplinie i morale oddziałów, w których rozpoczynali służbę. Nowi politrucy coraz częściej nie przypominali bowiem „starych", przedwojennych oficerów politycznych, nie dorównując im ani zdolnościami organizacyjnymi, ani też postawą ideowo-polityczną.

Tą zmianę jakościową szybko zauważyli Niemcy, podejmu jąc szereg kroków mających na celu rewizję zasad traktowania sowieckiej kadry politycznej. Pierwsze postulaty, sugerujące celowość umożliwienia sowieckim komisarzom i politrukom dostania się do niewoli, niemiecka generalicja zaczęła wysuwać już we wrześniu 1941 r. Jednak wyrażona przez Hitlera katego- 
ryczna odmowa rewizji założeń Kommissarbefehl położyła na pewien czas kres tym oczekiwaniom. Pojawiły się one ponownie wiosną 1942 r., doprowadzając do wydania w dniu 6 maja 1942 r. rozkazu odwołującego rozporządzenie z 6 czerwca $1941 \mathrm{r}$.

Rozkaz ów znalazł natychmiastowe przełożenie na tory propagandowe. Od tej chwili adresatami działań propagandowych mieli stać się sami sowieccy pracownicy polityczni, a nie jak dotychczas jedynie podburzani do aktów niesubordynacji przeciw nim oficerowie i żołnierze. Zgodnie $z$ nowymi wytycznymi celem zintensyfikowanej ulotkowej akcji antykomisarskiej miało być nakłonienie jak największej liczby sowieckich oficerów politycznych do rezygnacji z desperackiego oporu i zachęcenie ich do dezercji lub poddania się do niewoli. Pierwszą oficjalną ulotką, ilustrującą nową tendencję propagandy antykomisarskiej była opracowana jeszcze w maju $1942 \mathrm{r}$. ulotka sygnowana kodem 424/KP: „Pracownicy polityczni Armii Czerwonej! W ostatnim czasie do Niemców zaczęli przechodzić pracownicy polityczni Armii Czerwonej - komisarze i politrucy. Główną przyczyną ich przejścia, zgodnie z ich jednogłośnym oświadczeniem, okazuje się świadomość tego, że walczyli za przegraną sprawę, i że ta wojna to rezultat przestępczej polityki Stalina. Komisarze i politrucy oświadczaja także, że wbrew ich woli często zmuszani byli opierać swą pracę na oszukiwaniu szerokich mas czerwonoarmistów i że sprawą ich honoru i długu przed narodem staje się praca przy budowie nowego życia dla wyzwolonej Ojczyzny. Wśród przechodzących pracowników politycznych jest cały szereg komisarzy pułkowych i dywizy jnych. Mówią oni, że przeszliby i wcześniej, jeśliby wiedzieli, że obiecywane w niemieckich przepustkach dobre traktowanie przechodzących dobrowolnie - rozciąga się i na nich. Wobec tej okoliczności Naczelne Dowództwo Niemieckich Sił Zbrojnych oświadcza: Wszystkie niemieckie przepustki ważne dla żołnierzy i oficerów ogłasza się ważnymi dla wszystkich pracowników politycznych Armii Czerwonej. Naczelne Dowództwo Niemieckich Sił Zbrojnych" 22 .

W czerwcu 1942 r., podczas prowadzonych przez Wehrmacht wielkich operacji okrążających, propaganda niemiecka wprowadziła dodatkowo serię ulotek „kotłowych” o oznaczeniach kodowych 420-422 Kes. (niem. Kessel - kocioł). Ulotki różniły się jedynie nagłówkiem, w zależności od przewidywanych adresatów. Ulotka oznaczana kodem 420 Kes. miała nagłówek „Czerwonoarmiści!”, ulotka sygnowana 421 Kes. zatytułowana była „Ofice-

22 O. Buchbender, op. cit., s. 164. 
Ryc. 2. Ulotka 424/KP (przedruk za O. Buchbenderem, op. cit.)

\section{Попитработники \\ Красной Армии!}

За пос.леднее время $k$ немиам стали переходить политработники Красной Армин -- комиссары и политруки. Главной причиной их перехода, по их елиногласному заявленню, пвляется сознание того, что они боролись за гиблое дело, и что әта война - результат . преступной политикн Сталнна. Комнссары и полнтруки заявяяют так же. что против их воли они часто вынуждены были сгронть свою работу иа обмане широкнх красноармейских масс и что делом чести и долга нх перед народом является работа по строительству новой жизни для освобожденной Роднны.

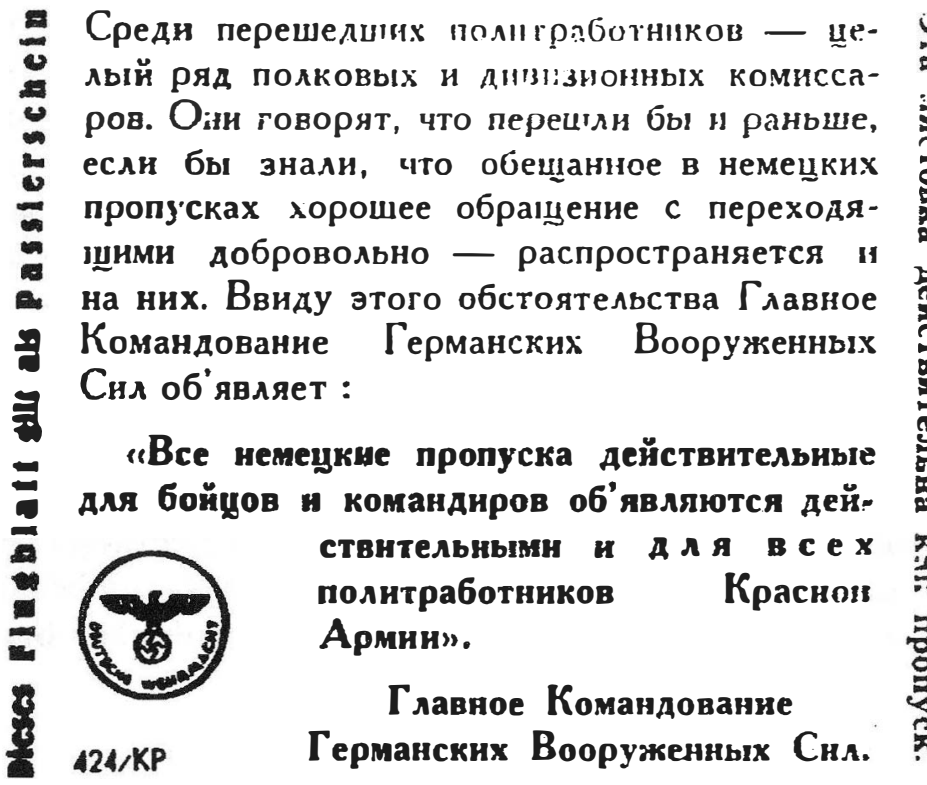


rowie!". Natomiast ostatnia $\mathrm{z}$ serii, oznaczona kodem 422 Kes., nosiła nagłówek „Pracownicy polityczni!”. Awers wszystkich ulotek zawierał rysunek stosu poskręcanego sowieckiego sprzętu wojskowego i ciał, otoczonego przez zwarty pierścień niemieckich czołgów. Napis informował: „Jesteście okrążeni! Lecz macie jeszcze jedno wyjście: przejść do Niemców i uratować tym swoje życie dla Ojczyzny!". Na rewersie ulotki 422 Kes. znajdował się tekst: „Pracownicy polityczni! Wiemy, że wielu z was tylko pod przymusem służy skazanemu na zgubę stalinowskiemu ustrojowi. Większość z was pojmuje całą zbrodniczość polityki morderców narodu. Walczyliście, bojąc się złego traktowania was przez Niemców. Wasze obawy są zbyteczne! Spokojnie przechodźcie do nas. My i wam gwarantu jemy dobre traktowanie! Z jeńcami obchodzimy się dobrze. Przechodzących dobrowolnie na naszą stronę, zgodnie z nowym rozkazem Hitlera, traktujemy jeszcze lepiej: otrzymuja oni specjalne zaświadczenie, zapewniające im lepsze wyżywienie i szereg innych ulg. Chcącym pracować zapewniamy pracę w zawodzie. Ta przepustka ważna jest dla nieograniczonej liczby żołnierzy, oficerów i pracowników politycznych Armii Czerwonej. Niemieckie dowództwo nie publikuje list jeńców wojennych. Ich nazwiska są ujawniane tylko na ich osobiste życzenie i tylko w tym przypadku, jeśli ich krewni znajdują się na wyzwolonym od bolszewików terytorium. Ta przepustka jest ważna do końca wojny. Na stronę wojsk niemieckich można przechodzić również bez przepustki. Wystarczy unieść ręce i krzyknąć «bagnety w ziemię!»»" 23.

Warto zwrócić uwagę na szczególnie istotny fragment tekstu ulotki 422 Kes., obiecujący sowieckim oficerom politycznym rezygnację z upublicznienia ich personaliów. Praktyka publikowania bądź ogłaszania poprzez stacje radiowe oraz instytucje Czerwonego Krzyża list sowieckich jeńców wojennych po raz pierwszy została zastosowana przez władze fińskie podczas wojny 1939-1940 r. Wywołało to falę doraźnych represji ze strony władz sowieckich wobec rodzin jeńców, w szczególności zaś kadry dowódczej. Analogiczne represje sankcjonował wspomniany wcześniej rozkaz Stawki Naczelnego Dowództwa nr 270 z 16 sierpnia 1941 r., w którym znalazło się osobiste polecenie Stalina: „Nakazuję: 1. Oficerów i pracowników politycznych, zdzierających z siebie podczas walki dystynkcje i dezerterujących na tyły lub poddających się do niewoli, uważać za złośliwych dezerterów, których rodziny podlegają aresztowi, jako rodziny łamiących przysięgę i zdradzających Ojczyznę dezerterów” 24. Stąd też obietnica zapewnienia swoistej „anonimo-

23 Ibidem, s. 189.

24 Prikaz Stavki Verchnogo Glavnogo Komandovanija Krasnoj Armii Nr 270..., s. 28. 
Ryc. 3. Ulotka 422/Kes. (przedruk za O. Buchbenderem, op. cit.)

\section{ПОЛИТРАБОТНИКИІ}

Hам известно, что многие из вас тольно по принундению слунат обреченному на гибель сталинсному строю. Большинство из вас понимает всю преступность политини убийц народа.

Вы боролись, боясь плохого обращения с вами у немцев. Ваши страхи напрасныl Спонойно переходите н нам. Мы и вам гарантируем хорошее обращение!

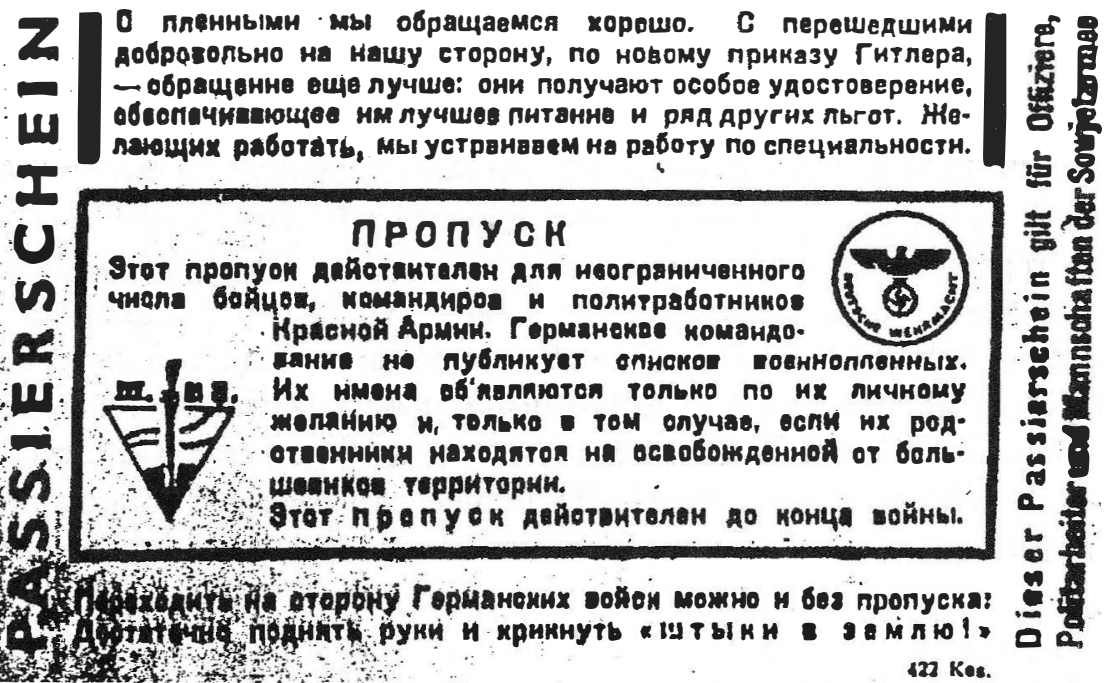


wości" sowieckim oficerom, w szczególności zaś komisarzom i politrukom, stawała się istotnym bodźcem, ułatwiającym podjęcie decyzji o poddaniu się do niewoli bądź dezercji.

Treści antykomisarskie pojawiły się jeszcze we wrześniu 1942 r., w ulotce sygnowanej kodem $480 \mathrm{RAB} / \mathrm{IX} .42$. Był to apel do żołnierzy Armii Czerwonej, podpisany przez wziętego do niewoli i współpracującego z Niemcami byłego dowódcę 2 Armii Uderzeniowej gen. lejtn. A. A. Własowa. Na rewersie ulotki znalazł się m.in. tekst: „Towarzysze oficerowie! Sowiecka inteligencjo! [...] Stalinowska klika winowajcą wszystkich niepowodzeń czyni oficera, wtedy, kiedy jest on w swych działaniach związany komisarzem, wydziałem politycznym i NKWD - ludźmi nie znającymi się na sprawach wojskowych" 25 .

Późnym latem 1942 r. intensywna dotąd propagandowa kampania antykomisarska zaczęła słabnąć. W sierpniu 1942 r., w pasie frontu i zaplecza podlegającym dowództwu prowadzącej intensywne działania zaczepne 6 Armii, zrzucono łącznie ponad $44 \mathrm{mln}$ ulotek. Główne tematy poruszane w ulotkach obejmowały: sytuację na froncie (10.609.44 sztuk - 24\%), antybolszewizm (7.515.020 sztuk - 17\%), propagandę skierowaną do dezerterów (6.630.900 sztuk - 15\%), dobre traktowanie w niemieckiej niewoli (4.862.660 sztuk - 11\%), antysemityzm (3.978.540 sztuk - 9\%), położenie Armii Czerwonej (3.094.420 sztuk - 7\%), odpieranie propagandy sowieckiej (2.652.360 sztuk - 6\%), sytuację na świecie (1.768.240 sztuk - 4\%), reformę rolną (1.326.180 sztuk - 3\%), propagandę skierowaną do komisarzy (884.120 sztuk - $2 \%)$ oraz propaganda skierowana do mniejszości narodowych $(884.120 \text { sztuk }-2 \%)^{26}$. Ulotki antykomisarskie stanowiły zatem jedynie niewielką część, choć należy pamiętać, iż treści antykomisarskie zawarte były również w ulotkach nawołujących do dezercji.

Ostatnia większa ulotkowa akcja antykomisarska miała miejsce jesienią 1942 r. Zainicjował ją sprawiający szereg problemów niemieckiej propagandzie, podpisany przez Stalina rozkaz ludowego komisarza obrony Nr 307 $O$ wprowadzeniu jednoosobowego dowodzenia w Armii Czerwonej i likwidacji instytucji komisarzy wojskowych w Armii Czerwonejz 9 października $1942 \mathrm{r}$. W znacznej mierze rozkaz ten był kalką analogicznego rozkazu z 14 sierpnia 1940 r. Ponownie likwidował on funkcje komisarzy wojskowych jednostek, przesuwając ich na stanowiska zastępców dowódców ds. politycznych. Odpowiedź na chwiejną politykę najwyższych sowieckich władz wojskowych ze

25 O. Buchbender, op. cit., s. 222.

26 Ibidem, s. 182-183. 
strony niemieckiej propagandy przyszła niemal natychmiast. W drugiej połowie października 1942 r. opracowana została seria 10 ulotek, sygnowanych kodami 565-578 KP/X.42. Motywem przewodnim tej akcji antykomisarskiej był zamiar przekonania szeregowych żołnierzy Armii Czerwonej, iż wydając rozkaz Nr 307 Stalin podjął próbę przerzucenia odpowiedzialności za dotkliwe klęski Armii Czerwonej z ich sprawców - komisarzy i politruków, na niewinnych dowódców liniowych.

Przykładem argumentów użytych w tej akcji pod wspólnym hasłem „Wszystko po staremu!” jest ulotka sygnowana kodem 566 KP/X.42: „Stalin jest i pozostanie kuglarzem! Raz, dwa, trzy - i komisarze są likwidowani i jeszcze raz, dwa, trzy i zlikwidowani komisarze siedzą znowu cało i wesoło na swoich miejscach. Nie nazywają się już wprawdzie komisarzami, lecz zampolitami. Wilki są syte i owce całe! [...] Co zmieniło się dla czerwonoarmistów po tym rozkazie? Komisarz pozostaje, tylko nazywa się inaczej. Specjalne wydziały pozostają, oddział zaporowy pozostaje, również Żyd siedzi jak przedtem na tyłach. Wszystko pozostało po staremu. Po co więc dalej przelewać krew za Stalina, skoro ta wojna jest przegrana? Po co więc oddawać życie za Żydów, którzy chcą nazywać się komisarzami lub zampolitami? Przechodźcie do nas, uratujecie swe życie dla waszych rodzin i waszej Ojczyzny!" 27. Charakterystyczną cechą tej ostatniej akcji antykomisarskiej była rezygnacja z prób oddziaływania bezpośrednio na samych pracowników politycznych i powrót do starych metod podważania ich autorytetu i pozycji wśród oficerów liniowych oraz szeregowych żołnierzy. Nikłe wyniki tej akcji, spowodowane postępującą stopniowo marginalizacją wpływu sowieckiej kadry politycznej na dowodzenie na polu walki, skłoniły Wydział Propagandy Naczelnego Dowództwa Wehrmachtu do rezygnacji z tego rodzaju form propagandy antykomisarskiej.

Trudno dziś oszacować wymierne efekty prowadzonej przez niemal 1,5 roku intensywnej propagandowej walki z sowiecką kadrą polityczną. Do pewnego stopnia pomocne mogą być w tym ogólne szacunki strat poniesionych przez pion polityczny Armii Czerwonej. W okresie od czerwca $1941 \mathrm{r}$. do maja 1945 r. wojska sowieckie utraciły bezpowrotnie łącznie 99.734 funkcjonariuszy pionu politycznego, co stanowiło $9,7 \%$ ogólnej liczby bezpowrotnych strat $w$ kadrze oficerskiej. Z tej liczby poległo lub zmarło od ran 57.608 oficerów politycznych, zaś 42.126 komisarzy i politruków zaginęło bez wieści 
lub dostało się do niewoli ${ }^{28}$. Większość spośród ponad 40.000 oficerów politycznych zaginionych bez wieści lub wziętych do niewoli należy uznać za zamordowanych, czy to w ramach Kommissarbefehl, czy też zagłodzonych w niemieckich obozach jenieckich w latach 1941-1942. Niepodobna jednak ustalić, ilu sowieckich pracowników politycznych padło ofiarami niemieckiej propagandy antykomisarskiej - za sprawą denuncjacji ze strony własnych podwładnych, czy też zamordowanych po dezercji na stronę przeciwnika bądź po poddaniu się do niewoli.

Nie ulega wątpliwości, iż propaganda antykomisarska, szczególnie prowadzona latem 1942 r., wywarła wpływ na stosunkowo niewielką grupę sowieckich pracowników politycznych, którzy przeżywszy poddanie się do niewoli, podjęli współpracę $\mathrm{z}$ władzami niemieckimi. Mylne byłoby stwierdzenie, iż rekrutowali się oni wyłącznie $\mathrm{z}$ młodszej kadry politycznej, w szczególności powołanej z rezerwy na przełomie 1941 i 1942 r. Wśród osób decydujących się na współpracę z Niemcami znajdowali się bowiem pracownicy polityczni średniego szczebla, a sporadycznie również wyższego. Przykładem jest postać komisarza brygadowego Gieorgija Mikołajewicza Żylenkowa, członka rady wojennej 32 Armii, wziętego do niewoli pod Smoleńskiem jesienią 1941 r. Związawszy się z Brygadą Osintorfską, a następnie z redakcją antysowieckiego pisma „Dobrowolec”, współredagował on tzw. manifest praski, pełniąc następnie funkcję szefa departamentu propagandy Komitetu Wyzwolenia Narodów Rosji i redaktora dziennika „Wola Naroda” ${ }^{29}$. Grupa byłych oficerów politycznych znalazła się w licznych, rozproszonych rosyjskich formacjach zbrojnych, tworzonych pod egida, Wehrmachtu i SS. Przykładem może być adiutant dowodzącego Rosyjską Ludową Armią Wyzwoleńczą (RONA) Bronisława Kamińskiego, młodszy politruk G. D. Biełaj ${ }^{30}$. Byli sowieccy oficerowie polityczni znaleźli się również w formowanych przez Niemców Ostlegionach - jedną z najgłośniejszych postaci był tu starszy politruk Musa Mustafowicz Zaliłow (znany szerzej jako poeta Musa Dżalil), korespondent wojenny w sztabie 2 Armii Uderzeniowej, wzięty do niewoli w czerwcu 1942 r. i pełniący służbę w Legionie Tatarskim ${ }^{31}$.

28 Grif sekretnosti snjat. Poteri voorużenych sil SSSR v vojnach, boevych dejstvijach $i$ voennych konfliktach. Statističeskoje issledovanie, Moskva 1993, s. 316.

29 C. Andreyev, Generat Własow i rosyjski ruch wyzwoleńczy, Warszawa 1990, s. 216.

30 S. Drobjazko, Lokotskoj avtonomnyj okrug i Russkaja Osvoboditelnaja Narodnaja Armija, w: Materiaty po istorii Russkogo Osvoboditelnogo Dvizenija. Stati, dokumenty, vospominanija, Moskva 1998, t. II, s. 190.

31 A. Okorokov, „Delo Bušmanova” ili suščestvovalo li sovetskoe podpole v škole propagandistov ROA, w: Materiały po istorii Russkogo Osvoboditelnogo Dviżenija..., s. 283. 
Niezależnie od powyższych faktów prowadzoną przez Niemców antykomisarską kampanię ulotkową należy uznać za nie spełniającą pokładanych w niej nadziei. Zaważyły na tym przede wszystkim błędy, jakie legły u podstaw planowania, skierowane przeciw komisarzom akcji propagandowych już wiosną 1941 r. Abstrahując od oceny zbrodniczego Kommissarbefehl, największym błędem było jego nieformalne ogłoszenie na całym froncie, za pomocą niewłaściwie sformułowanych ulotek, już w pierwszych dniach operacji „Barbarossa”. Skierowane do oficerów i żołnierzy Armii Czerwonej prymitywne, nacechowane wulgarnym antysemityzmem hasła, wzywające do niesubordynacji i agresji w stosunku do kadry politycznej, przeplatane były otwartymi zapowiedziami tragicznego losu komisarzy i politruków. Pojawiająca się po niewczasie świadomość popełnionego błędu najlepiej ilustruje wyrażona w listopadzie 1942 r. opinia szefostwa wywiadu 35 Dywizji Piechoty: „Popełniono błąd, wzmiankując o tym nawet w zrzucanych przez wojska niemieckie ulotkach. Byłoby celowe, gdyby traktowanie komisarzy utrzymano w tajemnicy" 32 . Rozpowszechnione w błyskawicznym tempie wzdłuż frontu informacje o przyjętych przez Wehrmacht zasadach traktowania poddających się sowieckich oficerów politycznych przyczyniły się do nasilenia stawianego przez nich oporu. Rozrzucane masowo niemieckie ulotki tylko utwierdzały sowieckich komisarzy i politruków w konieczności prowadzenia walki do przysłowiowego ostatniego naboju, często skłaniając ich do przedłożenia samobójczej śmierci nad poddanie się do niewoli. Znacznie skuteczniejsza okazała się II faza propagandowej akcji antykomisarskiej, realizowana latem 1942 r. Zmiana taktyki - rezygnacja z podżegania oficerów i żołnierzy przeciw pracownikom politycznym i próby nakłonienia ich do dezercji lub ufnego poddawania się do niewoli, zaczęła stopniowo przynosić efekty. Zostały one jednak zaprzepaszczone przez rezygnację $z$ tego rodzaju form kampanii propagandowej w październiku 1942 r., po ogłoszeniu sowieckiego rozkazu, likwidującego instytucję komisarzy wojskowych. Powrót do starych, znacznie prymitywniejszych metod propagandy antykomisarskiej doprowadził w końcu do jej zawieszenia, jako nieefektywnej.

32 Cyt za: S. Dattner, Zbrodnie Wehrmachtu na jeńcach wojennych armii regularnych w II wojnie światowej, Warszawa 1961, s. 119. 